Cuadernos de Historia Moderna

ISSN: 0214-4018

http://dx.doi.org/10.5209/CHMO.63921

\title{
Documentos de Edad Moderna en el Archivo General de la Administración
}

Daniel Gozalbo Gimeno ${ }^{1}$

Recibido: 18 de febrero de 2019 / Aceptado: 25 de marzo de 2019

Resumen. Este artículo tiene como objetivo presentar al público algunas fuentes documentales custodiadas en el Archivo General de la Administración susceptibles de ser utilizadas para la investigación del Antiguo Régimen en España, tanto en su faceta interior como exterior. Se describen en él las características y posibilidades de utilización de varios conjuntos de documentos relativos a la Deuda, la Beneficencia, las representaciones de la Monarquía en el exterior, el Consejo de Guerra, los Corregimientos de Madrid y Alcalá de Henares y algunos otros recursos de información, que son complementarios de los grandes fondos de Edad Moderna conservados en los Archivos Históricos Estatales.

Palabras clave: Archivo General de la Administración; Fuentes; Edad Moderna; Investigación.

\section{[en] Early Modern Documents in the General Archive of Administration}

\begin{abstract}
This paper aims at providing the reader with some insights into several record groups located in the General Archive of Administration at Alcalá de Henares that can be used to develop research on the Old Spanish Regime at national or international level. Relevant documentary sources about Public Debt, Private Charity, Spanish Monarchy representations abroad, the Council of War and the Corregimientos of Madrid and Alcalá de Henares are analysed as well as other resources, all them complementary to the great early modern period record groups preserved in the State Historical Archives.

Keywords: General Archive of Administration, Archival Sources; Early Modern History; Research Guides.
\end{abstract}

Sumario: 1. Preliminar. 1.1. Los expedientes de la Deuda. 1.2. El Archivo de la Beneficencia Particular. 2. Los fondos del Servicio Exterior y el Ministerio de Estado. 3. Los expedientes del Consejo de Guerra (1597-1834). 4. Los fondos de los Corregimientos: Madrid y Alcalá de Henares. Última consideración. Bibliografía.

Cómo citar: Gozalbo Gimeno, D. (2019) Documentos de Edad Moderna en el Archivo General de la Administración, en Cuadernos de Historia Moderna n 44.1, 205-227.

Archivo General de la Administración

E-mail: daniel.gozalbo@cultura.gob.es 


\section{Preliminar}

En 1969 el Archivo General de la Administración fue creado en Alcalá de Henares con el objetivo de recoger, seleccionar, conservar y disponer para información e investigación científica los documentos generados por los organismos centrales del Estado ya carentes de vigencia administrativa. Este hecho no puede ser desconectado de su hilatura histórica, que no es otra que la construcción del aparato burocrático liberal tras el fin del Antiguo Régimen. Este proceso generó a mitad del siglo XIX dos hechos fundamentales: la aparición del Cuerpo Facultativo de Archiveros y la creación en Alcalá de Henares del Archivo General Central, destinado a la custodia tanto de los documentos de las extinguidas Juntas y Consejos del Antiguo Régimen como de los expedientes administrativos que periódicamente remitirían los nuevos Ministerios liberales ${ }^{2}$. En 1939 el Archivo General Central desapareció traumáticamente del elenco de archivos estatales, mientras la producción documental administrativa crecía de un modo exponencial y espectacular. Sin archivo intermedio o histórico al que remitir sus documentos, los Ministerios acumularon desde entonces importantes masas documentales, muchas de ellas de notable antigüedad, y que hoy son testimonio de su actividad. Desde que el Archivo General de la Administración abrió sus puertas a principios de la década de 1970 han ingresado 1.163 transferencias procedentes de los Archivos Centrales de los Ministerios Civiles, Empresas Públicas y Organismos Autónomos, y del suprimido Movimiento Nacional, sin olvidar los fondos de las instituciones judiciales radicadas en Madrid.

Así pues, teniendo a la vista la norma y fines de su creación, a nadie pasa desapercibido que los fondos documentales albergados en el Archivo General de la Administración quedan acotados cronológicamente en el período de fundación y desenvolvimiento de las instituciones contemporáneas, desde el segundo tercio del siglo XIX hasta prácticamente la actualidad. Por tanto, con toda seguridad un usuario interesado en acceder a los documentos generados por el Estado en la Edad Moderna no anotará el archivo alcalaíno entre los primeros de su lista, o probablemente nunca lo hará.

No siendo un centro fundamental para ese campo de estudio, con todo, el Archivo General de la Administración custodia algunas fuentes que pueden ser de interés para

\footnotetext{
Como es sabido, el Archivo General Central, creado en 1858 y activo desde 1860, fue custodio de importantes fondos documentales de la Edad Moderna, ya que el Real Decreto fundacional de 17 de julio de 1858 le asignaba el cometido de recibir "los Archivos de las suprimidas Cámaras, Consejos y sus Presidencias". Efectivamente, hacia 1881 el cuadro de clasificación del Archivo General Central incluía los fondos del Tribunal de la Inquisición de Toledo, Tribunal de la Inquisición de Valencia, Cámara de Castilla, Audiencia de Madrid, Orden de San Juan de Jerusalén, Universidad Complutense, Universidad de Salamanca, Universidad de Valladolid, Colegiatas de Santa María y del Santo Sepulcro de Calatayud, Colegios y Casas de Jesuitas y Secretaría de Estado. Todos ellos fueron transferidos al Archivo Histórico Nacional a fines del siglo XIX, salvándose del fuego de 1939, pero otros documentos de Edad Moderna, pertenecientes a los fondos de los Ministerios de Fomento, Gobernación y Hacienda, Consejo Supremo de Guerra y Marina, Dirección General de Sanidad Militar, Tribunal de Cuentas e Iglesia Magistral de Alcalá de Henares, junto a los protocolos notariales modernos del distrito notarial, no corrieron la misma suerte. Más datos en Gozalbo Gimeno, D.: "El Archivo General Central (1858-1939). Aproximación a los fondos documentales desaparecidos", en Chamorro Merino, G. (ed.): El Palacio Arzobispal de Alcalá de Henares. Historia y Arquitectura, Alcalá de Henares, ARPA-Institución de Estudios Complutenses, 2014, pp. 199-222. Para conocer con detalle los fondos del Archivo General Central que poseían series iniciadas en la Edad Moderna, y valorar así el alcance de la catástrofe, es fundamental el cuadro de clasificación de 1897 custodiado en el fondo de la Junta Facultativa de Archivos, Bibliotecas y Museos del Archivo de la Biblioteca Nacional de España, Junta 11-010.
} 
el estudioso de la Edad Moderna española, tanto a nivel interno como en el marco de las relaciones internacionales o la acción exterior, y que en cualquier caso son susceptibles de convertirse en un útil complemento a las grandes series conservadas en los repositorios de fondos modernos, desde los Archivos Históricos Provinciales, Diocesanos, Universitarios, Municipales o Nobiliarios, hasta los Archivos Estatales como el Archivo de la Corona de Aragón, el Archivo General de Simancas, el Archivo General de Indias o el Archivo Histórico Nacional, por citar sólo algunos.

Pero, ¿por qué custodia el Archivo General de la Administración, un archivo intermedio, documentos de fechas tan antiguas? ¿Pudiera ser, acaso, una anomalía? Quizá se trate de un fenómeno habitual en los archivos centrales e intermedio de la Administración Central, receptores de fondos de instituciones contemporáneas en los que siempre hay cabida para series o agrupaciones documentales históricas. Es sabido que aún a día de hoy no son pocos los archivos públicos de rango central o administrativo que custodian series históricas, por tratarse de expedientes que siguen teniendo activo su valor primario, o por representar su permanencia en la organización productora un timbre de prestigio patrimonial para sus custodios. En otros casos, el desagüe de grandes masas documentales a las que no se podía dar salida durante decenios explica la llegada de documentos de cronología no habitual para archivos de tales características.

Sea como sea, en el Archivo General de la Administración pueden identificarse cuatro grandes fuentes de interés para el estudio de la Edad Moderna. No son las únicas, pero forman conjuntos lo suficientemente coherentes como para exponerlos de forma diferenciada:

1. Para empezar, hay que tener en cuenta las series documentales generadas en período contemporáneo por las nuevas instituciones de la Administración Central liberal que incorporaron en su acervo documentos de siglos anteriores en cumplimiento de sus competencias. Ejemplo de ello lo encontramos en los Expedientes de liquidación y conversión de deudas antiguas y cargas de justicia tramitados en el siglo XIX por la antigua Dirección General de la Deuda del Ministerio de Hacienda, y que suelen incluir títulos de deuda u otros derechos suscritos en el período moderno (y en ocasiones medieval); o en el denominado "Archivo de la Beneficencia Particular" del Ministerio de la Gobernación, que incluye, junto a los expedientes de fiscalización administrativa de las instituciones benéficas de los siglos XIX y XX, multitud de documentos de los siglos XVI al XVIII acreditativos de la fundación o institución de entidades de beneficencia privada. Se trataría de expedientes contemporáneos que incorporan documentos modernos o información sobre entidades originadas y activas en la Edad Moderna.

2. En segundo lugar encontramos los fondos documentales generados por las instituciones del Servicio Exterior de España, algunos de los cuales tienen fechas iniciales en el siglo XVIII. Estas representaciones, si bien no pueden sustraerse a los cambios estructurales político-administrativos acaecidos en la metrópoli, se mantienen estables funcionalmente a lo largo de los siglos, pues para ellas el final del Antiguo Régimen no supone un cambio significativo en la génesis documental y en la custodia de los documentos, los cuales se acumulan en sus archivos sin cesuras. En estos casos, el factor más importante para la integridad del fondo es la propia evolución política del país en que se sitúa la representación, y el ejemplo más claro se encuentra en las legaciones de la Corona española en los antiguos Estados de la 
Península Itálica previos a la Unificación de esa nación: por ejemplo, en el Reino de las Dos Sicilias, en el Ducado de Parma, o en el Gran Ducado de Toscana, de los que el Archivo General de la Administración custodia fondos diplomáticos de la Edad Moderna y de los dos primeros tercios del siglo XIX. Fuera del ámbito italiano, existen otros fondos diplomáticos que hunden sus cronologías en el siglo XVIII, tales como los de las representaciones de España en Trípoli, Washington o Estambul.

3. En tercer lugar, debe subrayarse la existencia de expedientes generados por el Consejo de Guerra, nacido a principios del siglo XVI dentro de la configuración polisinodial del Estado moderno. Estos documentos forman parte del fondo del Consejo Supremo de Justicia Militar, denominación que tomó a partir de 1939 el antiguo Tribunal o Consejo Supremo de Guerra y Marina, creado en 1834 para sustituir al antiguo Consejo de Guerra. La serie más importante de este fondo, abrumadoramente contemporáneo, es la de "Expedientes de causas, cruces, retiros y casamientos" en la que ha pervivido un número importante de expedientes de los siglos XVII y XVIII creados por el antiguo Consejo de Guerra, en su mayoría relativos a la gestión del personal de la institución y a los méritos y servicios de militares.

4. Finalmente, hay que citar varios fondos judiciales y gubernativos del Antiguo Régimen, de ámbito territorial más reducido, que se interrumpen con la aparición de las correspondientes instituciones sustitutorias liberales. Se trata de los fondos de los Corregimientos de Madrid y de Alcalá de Henares, ingresados como "sedimentos" documentales heredados por sus sustitutos, los Juzgados de Primera Instancia e Instrucción.

A continuación veremos con algo más de detalle estos documentos, su historia archivística, características descriptivas e instrumentos de acceso, de manera que el potencial usuario pueda calibrar su idoneidad para sus propósitos informativos o de investigación. Y en primer lugar:

\subsection{Los expedientes de la Deuda}

En septiembre de 1976 tuvieron ingreso en el Archivo General de la Administración siete remesas de legajos procedentes del Archivo de la Dirección General del Tesoro y Presupuestos del Ministerio de Hacienda ${ }^{3}$. De acuerdo a las relaciones de entrega, conformaban estas transferencias más de 2.800 legajos, de los cuales 1.406 correspondían a "expedientes de subastas y ventas de bienes de corporaciones civiles", 749 a "expedientes de deudas antiguas" y 717 a "expedientes de cargas de justicia", incoados y tramitados fundamentalmente en la segunda mitad del siglo XIX, acompañados de varios centenares de libros registro. Las transferencias fueron completadas con 55 legajos de juros, alcabalas, enajenaciones de oficios y servicios, remitidos por la citada Dirección General en julio de $1978^{4}$, entre los que se encontraron los documentos más antiguos que hoy custodia el Archivo General de la Administración ${ }^{5}$. Esta documentación venía acompañada de unas relaciones de

\footnotetext{
AGA, Registro General de Entrada de Fondos, transferencias registradas con los números 121, 123, 124, 125, 128, 129 y 130. Por entonces los asuntos de Deuda estaban a cargo de dicho centro directivo.

AGA, Registro General de Entrada de Fondos, transferencia registrada con el número 297.

El documento más antiguo data de 1299 y es una carta de privilegio de Fernando IV de Castilla concediendo exención de derechos de portazgo al Concejo de Niebla (Huelva). También existen cuatro privilegios rodados, de Fernando IV, Enrique II y Juan I, que han sido editados por Senent, M. a P.: "Los privilegios rodados del
} 
entrega que constituyeron los primeros instrumentos de descripción para su acceso y tratamiento. Recepcionadas las transferencias, pasaron a integrar el Grupo de Fondos de Hacienda, por entonces primera sección del Archivo.

Los expedientes de deudas antiguas y cargas de justicia deben situarse en el contexto histórico-administrativo del arreglo de la deuda que se inicia a mediados del siglo XIX de la mano de Juan Bravo Murillo y que se extenderá hasta bien entrado el siglo XX. En 1850 la deuda pública constituía una verdadera pesadilla para el Gobierno, pues representaba el $91 \%$ del producto interior bruto de la nación 6 . Bravo, en su calidad de Presidente del Consejo de Ministros y Ministro de Hacienda, procuró sentar las bases de un sistema que permitiera convertir la deuda gigantesca del Estado en otra que fuera asumible mediante los fondos realmente disponibles en las arcas estatales. Este es el espíritu de la Ley de 1 de agosto de 1851, que permitía reanudar el pago de los intereses de la deuda, paralizado desde 1836. Durante la segunda mitad del siglo XIX varias disposiciones en forma de leyes, decretos y órdenes regularán este esfuerzo estatal para el arreglo de la deuda, "verdadera transacción entre los derechos de los acreedores y la posibilidad de la nación de hacer frente a sus obligaciones"7, fielmente documentada en los expedientes de la Dirección General de la Deuda.

Jesús Gaite ya señaló en la década de 1980 el interés que podían suscitar estas series hacendísticas decimonónicas, "que nos permiten mirar con cierto optimismo la historia de nuestra Deuda Pública". Comparaba las transferencias al Archivo General de la Administración con las realizadas a principios del siglo XX por la Dirección General de la Deuda, cuando remitió al Archivo Histórico Nacional todo el fondo de Juros, poniendo de este modo "a salvo toda la historia de la Deuda de la Corona de Castilla, desde los Reyes Católicos hasta mediado el siglo XVIII". Efectivamente, ambos conjuntos documentales son complementarios, y si bien los expedientes de deudas antiguas y cargas de justicia se inician fundamentalmente en la segunda mitad del siglo XIX, enraízan con títulos de deuda del período moderno, pues son la base que permite la tramitación de aquéllos.

Archivo General de la Administración Central de Alcalá de Henares", Espacio, Tiempo y Forma, Serie III, Historia Medieval, t. V (1992), pp. 317-336. En general, la serie conserva privilegios reales de los siglos XIV y XV emanados de las cancillerías castellana, catalano-aragonesa y navarra.

6 García García, C. y Pro Ruiz, J.: “Arreglar la deuda para consolidar el estado: de Bravo Murillo a García Barzanallana (1851-1867)", en Álvarez Nogal y Comín, F.: Historia de la deuda pública en España (siglos XVI-XXI), Madrid, Instituto de Estudios Fiscales, 2015, pp. 187-220.

7 Exposición del Real Decreto de 29 de abril de 1853, mandando cese la conversión de la Deuda diferida en consolidada al 3 por 100. La legislación correspondiente al arreglo de la deuda forma un corpus ingente, que hace muy aconsejable la consulta de repertorios como el de Martínez Alcubilla para su compilación ordenada. Baste aquí citar la referida Ley de 1 de agosto de 1851 y los Reales Decretos de desarrollo de 1 de noviembre de 1851, con su instrucción de 31 de diciembre, el Real Decreto de 18 de diciembre de 1851 y el Real Decreto de 1 de octubre de 1852 .

8 Gaite Pastor, J.: "Los Archivos del Ministerio de Hacienda", Studia historica. Historia Contemporánea, 6-7 (1988-1989), pp. 207-208. Con todo, las series de la Deuda conservadas en el Archivo General de la Administración carecen de un alto índice de demanda por los usuarios, sobre todo si las comparamos con las de Clases Pasivas, que han suscitado grandísimo interés por la intensiva información biográfica que aportan. Confiamos en que esta situación pueda corregirse con su futura difusión en el Portal de Archivos Españoles (PARES). En todo caso, sigue siendo de gran interés para adentrarse en este filón documental el capítulo de Félix Val Latierro sobre el Archivo de la Dirección General de la Deuda y Clases Pasivas en la Guía de los Archivos de Madrid, Madrid, Dirección General de Archivos y Bibliotecas, 1952, pp. 227-253, que sintetiza la historia de la deuda, sus conceptos y sus series documentales. 
El arreglo de la deuda secular generó dos grandes series, a saber, los "expedientes de deudas antiguas" y "los expedientes de cargas de justicia". En el caso de los primeros se trata fundamentalmente de expedientes administrativos incoados de oficio o por iniciativa de las personas físicas y jurídicas que tienen como objeto la liquidación de un crédito contra el Estado mediante su reconversión en un título amortizable, capitalizando la deuda y haciéndola susceptible de pago por parte de la Hacienda Pública. Estas deudas antiguas podían originarse por conceptos muy diversos, de tal modo que es muy difícil en estas páginas explicar la amplísima casuística existente en la serie: así, unos expedientes pueden iniciarse con el objeto de indemnizar a los particulares consignatarios afectados por presas marítimas, como las realizadas por los británicos antes de $1808^{9}$; otros resuelven peticiones de atrasos adeudados a militares veteranos de las guerras contra Napoleón y de independencia americana, o a ciudades y particulares que financiaron el esfuerzo de guerra con contribuciones especiales ${ }^{10}$. Pero otros muchos se remontan más atrás en el tiempo, a un privilegio que originaba una obligación para la Hacienda Real, por ejemplo en forma de privilegio de juro cuyos intereses percibía el deudor en el "situado" de lugar y tributo que especificara el título correspondiente, y durante el plazo, temporal o perpetuo, que sus cláusulas estipularan. Así pues, son muy abundantes en estos expedientes los privilegios de enajenación de rentas reales (tercias, alcabalas, medios diezmos, etc.) a favor de individuos (con fuerte presencia de aristócratas, como es lógico) y entidades como concejos, colegios, cofradías, conventos, congregaciones, etc.

Los títulos originales o sus copias autenticadas ante los negociados del Ministerio de Hacienda están presentes dentro de los expedientes o fuera de ellos, como en el caso de los centenares de títulos del Antiguo Régimen que ingresaron en 1978 fuera de sus expedientes, quizá porque en un momento determinado se identificó un alto valor diplomático en estos documentos y se decidió formar un colección separada, hoy accesible a través del inventario IDD (01)008.000, que es un clásico catálogo documenta $1^{11}$. Otros dos inventarios dan acceso a la serie de deuda antigua: el IDD

9 Esto es así porque la indemnización de los consignatarios afectados por las presas marítimas británicas anteriores al año 1808 quedó a cargo del Estado, de modo que entre esta serie de liquidación de deuda pueden hallarse expedientes de indemnización a afectados por la pérdida de la famosa fragata Mercedes el 5 de octubre de 1804. Véase, como ejemplo: AGA, Hacienda, caja 11/12489, exp. 2: Expediente de indemnización a Joaquín María de Avendaño por valor de 114.539 pesos fuertes conducidos por varios buques apresados procedentes de Lima a Cádiz. Iniciado en 1852, no se concluirá su tramitación hasta 1903; se incluyen en él las certificaciones originales expedidas en 1804 por los capitanes de los buques y fragatas que componían el convoy, entre ellas la Mercedes.

10 El inventario elaborado en 1951 en la Sección de Liquidación de Deuda de la antigua Dirección General de la Deuda y Clases Pasivas relaciona los siguientes asuntos motivadores de expedientes de deudas antiguas y cargas de justicia: "Haberes del Clero; Haberes de personal exclaustrado; Haberes de militares y paisanos por las Guerras Civiles y Coloniales; Créditos al Estado por servicios, suministros, alquileres, material y análogos; Presas de guerra; Juros; Diezmos; Tercias; Alcabalas; Compensaciones; Depósitos y fianzas; Bienes procedentes de secuestros; Capellanías; Obras Pías; Fundaciones; Cofradías; Censos; Acciones del Banco de San Fernando y de San Carlos; Conversiones y extravíos de Títulos y Láminas; Abono de intereses; Renta del Tabaco; Enajenaciones; Ventas". Véase IDD (01)007.001, introducción.

11 Este instrumento también ofrece relación de algunos documentos que pudieran considerarse extraños a la serie de deuda (véanse pp. 149-153). Se trata de varios legajos de cuentas de gastos ocasionados por los ejércitos en Flandes entre 1586 y 1636, en las cajas 31293 a 31298 Top. 12/78; una cuenta justificativa de las cantidades concedidas al secretario Luis de Oyanguren para hacer frente a los reales gastos secretos en el año 1663, en las cajas 31298-31300 Top. 12/78; una cuenta del asiento con el banquero Lelio Imbrea sobre la provisión en Flandes y Génova para hacer frente a los gastos de la Armada, de 1637, en las cajas 31300-31303 Top. 12/78; 
(01)007.003, para la deuda antigua "cancelada", y el IDD (01)007.004, para la deuda antigua "pendiente", como así se distinguió en la antigua Dirección General de la Deuda, por llevar estampado el sello "cancelado" en la guarda de pergamino del título original o en la portada del expediente.

En el caso de los expedientes de "cargas de justicia" nos encontramos fundamentalmente ante procedimientos incoados de oficio o por las personas físicas o jurídicas perceptoras de rentas procedentes de tales obligaciones. El objetivo perseguido era la declaración de caducidad de la carga o, en caso contrario, la obtención de una indemnización, con cargo a los Presupuestos Generales del Estado, en concepto de liquidación de un derecho originado generalmente en un privilegio por el que la Corona enajenaba oficios o rentas en favor de una persona o entidad a cambio de una cantidad ${ }^{12}$. La indemnización adoptó la forma de una conversión de la renta heredada en deuda corriente del Estado, y requería la comprobación administrativa de que la carga de justicia no había caducado y que por tanto era perpetua y subsistente, circunstancias que se investigaban y sustanciaban en los expedientes con prolijidad, exigiendo para ello los títulos originales. Como en el caso de los expedientes de deuda, presentan un carácter diverso y complejo, siendo así que los propios archiveros de Hacienda reconocían en 1951 la dificultad de distinguir entre un procedimiento administrativo de liquidación de deuda de otro de cancelación de carga de justicia ${ }^{13}$.

En los expedientes de cargas de justicia originadas en la Edad Moderna, cuyos títulos o certificaciones se adjuntan a los expedientes o forman, como ya hemos visto, serie aparte, predomina el objetivo de liquidación y capitalización de juros por alcabalas, los más abundantes, pero también por conceptos fiscales tales como lanas, salinas, millones, mesa maestral de órdenes militares, puertos secos, venta de esclavos y negros, diezmos de mar; o por enajenación a favor de particulares de oficios públicos como, por ejemplo, el de fiel medidor de líquidos de Málaga, el de prebostad de Bilbao, el de escribano del servicio de millones de Paredes de Nava (Palencia), el de alguacil mayor de la Audiencia de Sevilla o el de regidor perpetuo de Toledo, citando algunos casos. Los centenares de privilegios conservados fueron

cuentas rendidas por Horacio Levante del asiento ajustado en 1627 para la provisión de la Real Armada del Mar Océano, de los años 1626-1634, en las cajas 31303-31304 Top. 12/78; pliegos de cargo sacados de los Libros de Flandes sobre cartas de pago contra varias personas (1634-1832), en las cajas 31304 y 31305 Top. 12/78; cartas de pago en favor del banquero Octavio Centurión y Negro como proveedor de la Factoría de Presidios de Cataluña desde 1633, en las cajas 31306-31307 Top. 12/78; y cédulas y decretos de Felipe V de los años 1708 y 1709 para el libramiento de cantidades a particulares en recompensa por servicios prestados, en el marco de la Guerra de Sucesión, en las cajas 31307-31309 Top. 12/78.

12 Para hacernos una idea de cuál era el objeto de las cargas de justicia es útil echar un vistazo al capítulo de gastos presente por este concepto en alguno de los Presupuestos Generales del Estado. Así, la Ley de Presupuestos del año 1885 contempla las siguientes obligaciones de la Hacienda en concepto de cargas de justicia: oficios y derechos enajenados; recompensas por salinas; asignaciones censuales sobre terrenos y derechos del Estado; recompensas por derechos, rentas y servicios; censos y pensiones afectas a fincas del Estado; y rentas vitalicias.

13 En las notas aclaratorias y de manejo del inventario original confeccionado en 1951 se da al usuario el siguiente consejo: "Cuando se trate de buscar un asunto de Deudas Antiguas o Cargas de Justicia, conviene hacerlo en los tomos de ambos conceptos, pues, dada la diversidad de materias que en ellas se comprenden, el precisar jurídicamente a qué concepto correspondían todos requería cierta especialización y técnica que no podía exigirse al personal auxiliar, frecuentemente renovado, que en su mayor parte ha confeccionado las fichas base de este inventario". Lo que explicaría la presencia de expedientes de deuda en la serie de cargas de justicia, y viceversa. Véase IDD (01)007.001, introducción. Los expedientes de cargas de justicia disponen del inventario IDD (01)007.005 para las cargas de justicia "canceladas", y del IDD (01)007.006, para las "pendientes". 
expedidos por las cancillerías de todos los soberanos titulares de la Monarquía de España, desde los Reyes Católicos hasta Carlos IV. La carta de privilegio es por antonomasia el documento representativo del Antiguo Régimen, ya que es justamente el privilegio la piedra basilar de su estructura sociopolítica.

La diversidad de privilegios y títulos expedidos por la Hacienda Real, sobre los conceptos más diversos y a favor de un mundo social heterogéneo, hace de estas series un conjunto documental a tener en cuenta para la investigación de la fiscalidad, la deuda pública y la administración de la Monarquía Hispánica y el Estado Liberal, en combinación con los fondos hacendísticos conservados en el Archivo General de Simancas y en el Archivo Histórico Nacional. Además, ofrece a estudiantes e investigadores una panoplia de tipos documentales de gran interés para el análisis diplomático-paleográfico y para la historia de la cultura escrita. Por otra parte, en estos expedientes no cuenta únicamente la existencia de los títulos originales de derechos constituidos en los siglos modernos, sino también la información acerca de las personas físicas y jurídicas que deciden convertirse en acreedores del Estado en ese período. Para cobrar/convertir la deuda, era esencial que tales entidades dieran prueba de su existencia y continuidad ante los negociados de Hacienda decimonónicos, y para ello constan también en los expedientes las correspondientes certificaciones de los hechos fundacionales. Podía tratarse de fundaciones pías como el Colegio de la Encarnación, vulgo "Casa de Recogidas", de Salamanca, fundado en 1648, cuyo patrón era el cabildo de la Catedral, y que había quedado exento de desamortización ${ }^{14}$. En este sentido, los expedientes de deudas antiguas y cargas de justicia proveen de información notable sobre el origen y vicisitudes de estas instituciones tan propias del Antiguo Régimen.

\subsection{El Archivo de la Beneficencia Particular}

Si los expedientes de deudas antiguas y cargas de justicia nos hablan del esfuerzo del Estado liberal por identificar, comprobary tratar de liquidar y consolidar las obligaciones contraídas por la Corona siglos atrás, aliviando a las arcas públicas de tan pesada rémora, los documentos del llamado "Archivo General de la Beneficencia Particular" ilustran sobre la función de control y fiscalización que ese mismo Estado liberal extendió a las entidades asistenciales privadas, muchas de ellas fundadas en los siglos modernos y pasadas por el tamiz del proceso desamortizador. El Archivo General de la Beneficencia Particular ingresó en el Archivo General de la Administración en diciembre de 1976, mediante transferencia de 1.373 cajas que se encontraban en el edificio que fue sede de la Junta Provincial de Asistencia Social de Madrid, cajas que iban acompañadas de 569

14 AGA, Hacienda, caja 11/12505, exp. 14: Expediente incoado por Robustiano Boada, apoderado del Colegio de Recogidas de Salamanca, sobre liquidación de una lámina de deuda corriente al 5\% no negociable $\mathrm{n}^{\circ} 735$ presentada con carpetas números 3641 y 3642. Tramitado entre 1862 y 1864, este expediente incluye una certificación de la fundación de "una casa y recogimiento de aprobación con el nombre y título de la Encarnación, destinada al recogimiento de mugeres pecadoras" mediante escritura pública fechada en 21 de abril de 1648 otorgada por Gabriel de Solís, regidor perpetuo de Salamanca, y su esposa Feliche Alonso. Este ejemplo de institución benéfica ha sido tomado al azar entre muchos otros existentes en los expedientes. De hecho, el fondo documental de la Casa de Recogidas de Salamanca se custodia en el Archivo Catedralicio salmantino y ha sido objeto de pesquisa por parte de los investigadores, pero he aquí que no siempre estas instituciones cuentan con una poderosa institución eclesiástica que se haga cargo de sus papeles, de modo que, ante la ausencia de datos, la información secundaria que ofrecen los expedientes estatales de la deuda antigua no puede ser ajena al estudioso. 
legajos y 123 libros del Archivo de la Junta Provincial de Beneficencia de Madrid ${ }^{15}$. Es fundamental recalcar, como hace Juan José Villar Lijarcioo ${ }^{16}$, que el Archivo de la Beneficencia Particular siempre tuvo una ubicación y un tratamiento diferenciados respecto al Archivo Central del Ministerio de la Gobernación, así como una relación especialísima con la Junta Provincial de Beneficencia de Madrid, en cuya sede de la calle Amor de Dios $\mathrm{n}^{\circ} 6$ fueron constituyéndose tanto el fondo del Archivo General como el de la Junta Provincial.

Este conjunto documental, cuyo productor fue la Sección de Beneficencia Particular de la Dirección General de Beneficencia (y en ocasiones la de Administración) del antiguo Ministerio de la Gobernación, alberga informaciones esenciales para la acción del Protectorado del Gobierno en este ramo, esto es, "la ordenación, fiscalización y alta inspección de las obligaciones, bienes y recursos adscritos a fundaciones benéficas particulares" en aplicación del marco normativo establecido por la legislación decimonónica de Beneficencia ${ }^{17}$, que tenía como objetivo asegurar que las entidades privadas cumplieran la voluntad de sus antiguos fundadores y no desviaran sus recursos hacia fines distintos a los de su creación. Así pues, las series de este fondo se inician administrativamente en la década de 1830 y finalizan un siglo después, cuando se aprecia una decadencia de la beneficencia privada de origen religioso o testamentario al extenderse progresivamente la acción asistencial estatal. En cualquier caso, contienen tipologías diversas y ricas: expedientes de declaración y clasificación de fundaciones, expedientes de investigación de su estado, estadística, cuentas y presupuestos de las mismas, correspondencia con las Juntas Provinciales de Beneficencia, etc. Por lo general, el tratamiento archivístico que recibió cada fundación fue la apertura de un legajillo o expediente general en el que se iban incorporando todos los documentos relativos a la institución a medida que se iban produciendo o recibiendo.

Además, era totalmente imprescindible para una correcta gestión de la Beneficencia Particular disponer de los documentos que efectivamente acreditaran el origen, desarrollo y vigencia jurídica de la fundación benéfica, así como de los bienes y rentas sobre los que se sustentaba. Dada la existencia plurisecular de una buena parte de las fundaciones, es posible encontrar como cabecera de los expedientes generales un buen número de títulos originales de fundación a partir del siglo XVI, en forma de escrituras notariales, capítulos, actas de patronazgo y rendición de cuentas, que alcanzan hasta siglo XIX ${ }^{18}$. En ocasiones se trata de libros registro encuadernados en

15 AGA, Registro General de Entrada de Fondos, transferencia registrada con el número 161.

16 Villar Lijarcio, J. J.: "La provincia de Jaén en el Archivo de la Beneficencia Particular", Códice. Revista de Investigación Histórica y Archivística, 26 (2012), pp. 31-40.

17 Ibidem, pp. 31-32. Entre la legislación sobre Beneficencia Particular merece la pena destacar los textos siguientes: la Ley de Beneficencia de 1849, su reglamento de ejecución de 14 de mayo de 1852, la Instrucción para el ejercicio del Protectorado del Gobierno en la Beneficencia aprobada por Real Decreto de 27 de abril de 1875 y el Real Decreto e Instrucción de 14 de marzo de 1899 para el ejercicio del Protectorado del Gobierno en la Beneficencia Particular. Una útil introducción histórica, seguida de textos normativos y documentos de diversa índole pueden encontrarse en la obra de Maza, E.: Pobreza y beneficencia en la España contemporánea (1808-1936), Barcelona, Ariel, 1999.

18 En este sentido, todavía puede reconocerse hoy en la estructura archivística de este fondo el tenor del artículo 46 de la Instrucción de 27 de abril de 1875 para el ejercicio del Protectorado del Gobierno en la Beneficencia: "Todos los títulos de fundación y de propiedad, escrituras, estatutos, constituciones, reglamentos y disposiciones oficiales que autoricen, modifiquen, agreguen o supriman alguna fundación de Beneficencia, formarán bajo el nombre de ésta, en el Archivo de la Sección, un legajo especial, para que pueda ser consultado en cuantos expedientes lo necesiten, sin ocasionar nuevas molestias ni gastos innecesarios a los interesados". 
pergamino que se inician con el documento original de creación de una memoria $u$ obra pía, seguido de los asientos que de forma cronológica y sistemática van dando cuenta de los distintos actos jurídicos de voluntad y patronazgo que determinan las condiciones de desenvolvimiento de la institución, tal y como puede observarse en el caso de la memoria fundada en 1590 por Juana del Monte para dotes de huérfanas y limosnas, con sede patronal en la hoy desaparecida iglesia de San Miguel de los Octoes de Madrid ${ }^{19}$. En otras ocasiones, pueden encontrarse ejemplares impresos de las ordenanzas o reglamentos de las instituciones, como la segunda impresión, de 1712, de los estatutos de la Santa Capilla y Obra Pía para casar huérfanas y vestir pobres fundada en 1512 en la parroquia de San Andrés de Jaén por el protonotario apostólico Gutierre González Doncel ${ }^{20}$.

O puede tratarse de certificaciones, testimonios y copias autorizadas de los documentos fundacionales y su normativa interna, expedidas contemporáneamente a los procedimientos administrativos decimonónicos de comprobación y fiscalización, como podemos observar nuevamente en el caso de la Casa de Arrepentidas de Salamanca, arriba citada, y que reaparece ahora en el Archivo de la Beneficencia Particular con su legajillo específico, y donde nos volvemos a topar, en traslado de 1841, con la escritura de fundación de 1648, esta vez in extenso, acompañada de la relación de fincas y rentas que los fundadores y patronos destinaron para su dotación ${ }^{21}$. En este caso, las comprobaciones del Ministerio de la Gobernación tienen como objetivo verificar la legalidad de la obra pía y la correcta administración y asignación de rentas y bienes. Finalmente, pueden existir informaciones contemporáneas que resumen la historia de la institución benéfica desde su creación, a efectos de identificar su titularidad jurídica, siendo habitual que los expedientes se abran con una "reseña histórica de su fundación", de gran interés para aquéllas de las que ha quedado escaso rastro documental ${ }^{22}$.

19 AGA, Interior, caja 44/06319. La administración de esta memoria, a la que se unió la fundada por Alonso del Monte, ocupa diversos libros, que alcanzan el siglo XIX. La antigua provincia de Madrid tiene, en el Archivo General de la Beneficencia Particular, una presencia superior a la del resto de provincias, pues, además de los documentos generados por la Dirección General de Beneficencia del Ministerio de la Gobernación, integra también una parte del fondo de la Junta Provincial de Beneficencia, al que pertenecen los libros de la fundación de Juana del Monte. Otra parte del fondo documental de la Junta Provincial de Beneficencia de Madrid se conserva hoy en el fondo de la Diputación Provincial en el Archivo Regional de la Comunidad de Madrid.

20 Villar Lijarcio, op. cit. (nota 16), p. 45. El amigo y autor de este artículo ha llamado mi atención sobre la rareza de este impreso, que se conserva en AGA, Interior, caja 44/05778, lo que le agradezco.

21 AGA, Interior, caja 44/06839, exp. 3368: Expediente de la Casa de Beneficencia (vulgo Recogidas) de Salamanca.

22 En el expediente de la Casa Cuna de Ciudad Rodrigo se encuentra una de esas reseñas, fechada en octubre de 1858: “...en virtud de una orden espedida por el Supremo Consejo de Castilla en 25 de junio de 1771, y a instancia del reverendo Obispo Don Cayetano Cuadrilleros, se mandó construir en Ciudad Rodrigo un edificio casa cuna para atender a la criación de los niños espósitos de que hasta entonces cuidaba el reverendo Obispo y su Cavildo. No se dio principio a dicha casa por falta de suficientes recursos hasta el 26 de marzo de 1778, quedando concluida en poco tiempo, pero que constando el día y año fijo de su conclusión, tampoco se sabe el día en que empezaron a recibir en ella sus recogidos, que fue luego tan pronto como se concluyó. En esta casa se recibieron desde el principio no sólo los niños, que fue el principal objeto de su fundación, sino también ancianos y desgraciados, viniendo a ser a la vez que casa de cuna, casa de misericordia y desamparados; sobre ella conservó siempre la corona el derecho de patronato, y así continuó hasta el año de 1810, en que, maltratada la ciudad a causa de las guerras, quedó arruinado casi enteramente el edificio con sus fábricas; el cual reedificado después en una parte, quedó como hoy se conserba en el solo concepto de casa cuna y bajo la misma administración que hoy tiene con poca diferencia, a cargo y bajo la inmediata dependencia de la Junta Provincial de Beneficencia, que la considera como hijuela o filial de la de Salamanca": AGA, Interior, caja 44/06839, exp. 3369. 
En complemento a los fondos que sobre beneficencia privada custodian los Archivos Históricos Provinciales, de Diputaciones Provinciales, Municipales, Notariales Eclesiásticos y privados, el Archivo General de la Beneficencia Particular aporta datos sobre hospitales, cofradías, casas de huérfanos, escuelas de párvulos, ollas de pobres y platos de pobres vergonzantes, casas de desamparados, memorias y obras pías para la dotación de huérfanas, doncellas y arrepentidas, etc., etc., en un extenso arco temporal. En la actualidad este fondo ocupa el tramo de cajas comprendido entre la signaturas 44/05000 y 44/07613. Es accesible a través de 51 inventarios mecanografiados, IDDs (08)005.001-(08)005.051, correspondiendo cada uno de ellos a una provincia ${ }^{23}$, donde cada página ejerce la función de ficha descriptiva del contenido documental de una institución benéfica.

\section{Los fondos del Servicio Exterior y el Ministerio de Estado}

Otro vivero documental de interés para el modernista es el constituido por los archivos de legaciones y consulados de España en distintos puntos del planeta, existiendo varios en el Archivo General de la Administración que arrancan su andadura en el siglo XVIII. Su correspondencia con las instituciones centrales de Madrid, con las representaciones de que dependían y con las autoridades de las naciones en que se radicaban, sus expedientes y registros de asuntos comerciales, judiciales, notariales y de navegación, por citar algunos de tantos, aportan información para el estudio de la actividad exterior española en el período final del Antiguo Régimen, tanto en la esfera pública como privada, en lógico complemento a los fondos generados por la Primera Secretaría de Estado y del Despacho, por el Consejo de Estado y por otras representaciones diplomáticas, conservados hoy en el Archivo Histórico Nacional y en el Archivo General de Simancas. De manera habitual, se trata de agrupaciones documentales de muy larga duración, pero que generalmente son de volumen discreto, al ser su contenido el material superviviente a multitud de contingencias, selecciones y mermas intencionadas y naturales sucedidas hasta el momento de su envío a la metrópoli.

Así, el 30 de abril de 1973, con las obras del archivo prácticamente terminadas, tuvo ingreso, entre un conjunto diverso de fondos del Servicio Exterior procedentes del Ministerio de Asuntos Exteriores, uno del Consulado de España en Burdeos ${ }^{24}$, cuya documentación más antigua, la correspondencia con el Secretario de Estado Ricardo Wall sobre apresamiento de buques por corsarios franceses, databa de mayo de 1756. Sin embargo, va a destacar por su importancia, número y volumen el conjunto de archivos formados por las legaciones y consulados de España en los estados italianos durante el siglo XVIII y buena parte del XIX, los más numerosos a causa de las estrechas relaciones mantenidas entre los territorios de ambas Penínsulas desde tiempos medievales, territorios que en muchos casos estuvieron bajo dominio directo de la Monarquía Hispánica, como Nápoles y Sicilia. Así, junto a los documentos de

23 Excepto el último, IDD (08)005.051, que relaciona documentación varia y suelta que no puede incluirse en la sistematización del fondo documental, y que versa, entre otros asuntos, sobre las Juntas Generales de Beneficencia y el Hospital de Santa Catalina de los Donados, que fue la primitiva sede de la Junta Provincial de Beneficencia de Madrid.

24 AGA, Registro General de Entrada de Fondos, transferencia registrada con el número 16. El inventario que da acceso a este fondo, con descripción bastante detallada, es el IDD (10)029.000. 
Burdeos (1756-1900), ingresaron en la citada transferencia un fondo del Consulado en Palermo (1766-1948) ${ }^{25}$ y otro del Consulado en Trieste (1725-1938) 1974, con las obras ya terminadas, tuvo ingreso un importante fondo del Consulado de España en Génova (1756-1939) ${ }^{27}$. Como es natural por su función tradicional, los fondos consulares abundan en asuntos comerciales y de navegación, sanidad, asuntos judiciales, protección de súbditos y demás circunstancias de los españoles en el exterior, pero también la política se trasluce en sus series de correspondencia.

Estos fondos consulares serían completados en abril de 1984 con la llegada de 131 cajones que, sin relación de entrega alguna, contenían en gran mezcla y desorden los fondos de representaciones diplomáticas de España en diversas capitales de Italia, que habían sido concentrados en nuestra Embajada en Roma (Quirinal $^{28}$. Abiertos los sellos diplomáticos y los del servicio aduanero italiano en junio de 1985 en presencia de los archiveros Elio Lodolini y Luigi Londei, se descubrió una amalgama desordenada de documentos, algunos en lamentable estado de conservación, pertenecientes a representaciones diplomáticas de España ante los Estados italianos y, en menor número, de algunas representaciones italianas ante otros Estados de la misma Península Itálica. A partir de 1989 se iniciaron los trabajos de identificación y descripción, hallándose conjuntos relevantes de los Archivos de la Legación de España ante el Reino de las Dos Sicilias (Nápoles, 1756-1863), la Legación de España ante el Ducado de Parma (1740-1805), la Legación de España ante el Gran Ducado de Toscana (Florencia, 1711-1798), la Legación de España ante el breve Ducado de Lucca (1818-1842) y la Legación de España ante el Reino de Cerdeña-Saboya (Turín, 1814-1865), además de una parte relevante del fondo documental de la primera representación diplomática española ante el nuevo Estado Italiano asentado en Roma tras la unificación del país. Como es natural, los asuntos diplomáticos, protocolarios y de alta política son más abundantes en los documentos de estas legaciones que en los consulares ${ }^{29}$.

En este sentido, cabe destacar igualmente el fondo de la Legación de España en Suiza (Berna-Lucena, 1769-1917), formado por unas escasas 21 cajas, pero que contienen abundante correspondencia diplomática de la segunda mitad del siglo XVIII, siendo de especial interés para la historia militar de España la documentación relativa al reclutamiento y formación de los regimientos suizos que estuvieron al servicio de la Corona hasta la década de $1820^{30}$. Otro fondo diplomático importante es el de la Legación de España en Washington (1778-1981), que inicia sus series

25 Accesible a través del inventario IDD (10)046.000, mecanografiado.

26 Accesible a través del inventario IDD (10)049.000, mecanografiado.

27 AGA, Registro General de Entrada de Fondos, transferencia registrada con el número 37. El instrumento actualmente disponible es el IDD (10)041.000, mecanografiado.

28 AGA, Registro General de Entrada de Fondos, transferencia registrada con el número 709.

29 En la actualidad ocupan estos fondos un total de 422 cajas normalizadas (signaturas 54/13443-54/13864), más un conjunto de libros registro. En cuanto a su acceso, tiene la peculiaridad de contar con una descripción disponible on-line, a través de la base de datos de la "Guía de Fuentes Documentales" en la página web de los Archivos Estatales http://www.culturaydeporte.gob.es/cultura-mecd/areas-cultura/archivos/bases-de-datos. html. Para realizar una búsqueda óptima es necesario seleccionar la opción "Guía de Fuentes de Historia de Europa" y seguidamente introducir en el campo "Archivo" el nombre del Archivo General de la Administración. Con estos requisitos ya podemos recuperar todos los registros, pero es recomendable afinar la búsqueda filtrando a través del resto de campos de interés.

30 Este fondo es accesible a través del inventario IDD (10)083.000. Ingresado junto a los fondos italianos recién mencionados. 
en fechas próximas al nacimiento de los propios Estados Unidos; además, su correspondencia con la Secretaria de Estado y con las autoridades gubernativas de la América y Filipinas españolas tiene un volumen suficiente como para ser tenida en cuenta en investigaciones sobre las primeras relaciones diplomáticas hispanoestadounidenses y el fin de nuestra presencia colonial en el continente americano ${ }^{31}$.

En relación a África se encuentra disponible el fondo del Consulado General de España en Túnez (1796-1920), cuyas tres primeras cajas abarcan el período 17861832 , con muy escasos testimonios del siglo XVIII ${ }^{32}$. Seguidamente contamos con el fondo del Consulado General de España en Trípoli (1779-1932) ${ }^{33}$. De sus escasas 19 cajas, las siete primeras contienen correspondencia diplomática oficial, expedientes de navegación, de corsarios, desertores, etc., para el período 1779-1828; las cajas se complementan con otros 19 libros, entre los que destaca un tomo del protocolo notarial consular de los años 1784-1814, de interés para el estudio de la vida cotidiana de los españoles en las llamadas "Regencias de África". No en vano, la paz con estas Regencias y con el Imperio Otomano era un objetivo perseguido por la diplomacia española, tal y como se declara en diversos puntos de la Ynstrucción dada por el Rey a la Suprema Junta de Estado ${ }^{34}$ en 1787, de modo que el fondo de la Legación de España en Constantinopla (1777-1905) también puede ser relevante para iluminar este punto de la política exterior de la Monarquía hacia la Sublime Puerta. En el orden cultural, los testimonios de la labor de los dragomanes para hacer posible la comunicación diplomática son otra parte destacable de este conjunto documental ${ }^{35}$.

Este repaso por los fondos diplomáticos más antiguos no quedaría completo si dejáramos de citar la existencia de pequeños grupos documentales de Edad Moderna en el fondo del Ministerio de Estado custodiado en el Archivo General de la Administración. En efecto, una parte del llamado "Archivo Histórico" del Ministerio de Asuntos Exteriores fue transferida a Alcalá en abril de $1973^{36}$. Fueron remesadas entonces algunas series relativas a las secciones ministeriales de Subsecretaría, Contabilidad, Interpretación de Lenguas, Relaciones Culturales, Comercio y Asuntos Judiciales, arrancando algunas de ellas en tiempos de la antigua Primera Secretaría de Estado y del Despacho, en el siglo XVIII o incluso antes. No es posible

31 AGA, Registro General de Entrada de Fondos, transferencia registrada con el número 37, ingresada en julio de 1977. Este fondo es accesible a través del inventario IDD (10)026.001.

32 AGA, Registro General de Entrada de Fondos, transferencia registrada con el número 16, ingresada en abril de 1973. Este fondo es accesible a través del inventario IDD (10)085.000.

33 AGA, Registro General de Entrada de Fondos, transferencia registrada con el número 778, ingresada en abril de 1985. Este fondo es accesible a través del inventario IDD (10)054.000.

34 La redacción original manuscrita de este texto capital de Floridablanca destinado a dotar de un proyecto político a la Junta Suprema, en forma de prontuario de Estado, se encuentra en AHN, Estado, leg. 2808. José Luis Bermejo Cabrero lo publica y coteja con la versión abreviada remitida a la imprenta en sus Estudios sobre la Administración Central española (Siglos XVII y XVIII), Madrid, Centro de Estudios Constitucionales, 1982, pp. 223-255.

35 AGA, Registro General de Entrada de Fondos, transferencia registrada con el número 16, ingresada en abril de 1973. Este fondo es accesible a través del inventario IDD (10)087.000.

36 AGA, Registro General de Entrada de Fondos, transferencias registradas con los números 15 y 16 . En 2012 el Archivo General del Ministerio de Asuntos Exteriores remitió la práctica totalidad de los fondos documentales que conservaba en su sede de Plaza de la Provincia al Archivo Histórico Nacional y al Archivo General de la Administración. Al primero llegó la parte restante del "Archivo Histórico", esto es, los documentos hasta 1930 fundamentalmente, caracterizados por su signatura "H", y al segundo el llamado "Archivo Renovado", es decir, el fondo del Ministerio de Estado/Asuntos Exteriores desde el año 1931 aproximadamente, caracterizado por sus signaturas "R". 
detenernos en todos los testimonios de Edad Moderna que se espigan en este fondo del Ministerio de Estado, pero desde luego merece la pena hacer mención a algunos, y el primero de ellos es el denominado "Expediente general sobre organización del Ministerio de Estado", que reúne documentos datados entre 1707 y 1922, en tres cajas, 54/00039 a 54/00041. En la primera de ellas, albergando los documentos más antiguos, se reúne información de interés sobre la planta de la Primera Secretaría de Estado y del Despacho, las normas de procedimiento y gobierno interior, reparto de negociados ${ }^{37}$, honores de los Secretarios del Despacho y dignidades y cargos anejos al oficio, asuntos de personal, retribuciones extraordinarias y gastos secretos del real servicio, del período 1707-1839.

Entre los expedientes que hemos tenido a la vista también habría que destacar uno procedente de Sección de Contabilidad (edificios de representaciones en el extranjero) del año 1747 relativo a la posible instalación de los pensionados de la Real Academia de Bellas Artes de San Fernando en el edificio de nuestra Embajada ante la Santa Sede, en la Piazza di Spagna, que incorpora unos magníficos planos y alzados del palacio adquirido por el VIII Conde de Oñate en $1647^{38}$. Al lado de este expediente, en la misma caja, se halla el Discurso sobre los Archivos, y expecialmente del Archivo de Su Magestad Cathólica en la Corte de Roma, de José García del Pino, secretario de la Real Casa de Santiago de los Españoles de Roma y archivero de la Embajada de España ante la Santa Sede. Redactado hacia 1716, es de gran interés para los archiveros por las consideraciones teóricas y prácticas que aduce en el diseño de los requisitos de un archivo diplomático y las condiciones de su responsable a principios del siglo XVIII ${ }^{39}$.

No falta tampoco la tradicional agrupación documental de "Varios" donde encontramos una colección facticia de normativa impresa de la Edad Moderna compilada probablemente en la misma Primera Secretaría de Estado y del Despacho. Se trata de impresos de Reales Cédulas publicadas por el Consejo de Castilla, así como Reales Provisiones, Reales Resoluciones, Reales Órdenes, Pragmáticas y otros textos normativos datados e impresos entre 1600 y 1833. Su número supera

37 Pertenece este expediente general a las series de la Subsecretaría, y ha sido utilizado por Beatriz Badorrey Martín en su estudio sobre Los orígenes del Ministerio de Asuntos Exteriores (1714-1808), Madrid, Ministerio de Asuntos Exteriores, 1999.

38 AGA, Asuntos Exteriores, caja 54/00261. Estos planos iban acompañados de una copia de la impresionante Recentis Romae ichnographia et hypsographia sive planta et facies ad magnificentiam quae sub Alexandro VII P.M. urbs ipsa directa exculta et decorata est por el arquitecto y grabador Giovanni Battista Falda, impresa en Roma en 1667. Todo ha sido extraído de su expediente de origen, encarpetado e instalado en mueble planero para su más eficaz conservación. Ha sido objeto de investigación por Mercedes Simal López: "El Palacio de España en Roma a través de los dibujos de Ferdinando Puga y José de Hermosilla”, en Archivo Español de Arte, 2008, n 321, pp. 31-48.

39 AGA, Asuntos Exteriores, caja 54/00261. Algunas de sus consideraciones podrían trasladarse a la actualidad, en lo tocante a los documentos creados por los más altos gabinetes: "Será muy acertado que al fin de cada Ministerio se entren en el Real Archivo los despachos y escrituras del tal Ministerio para que se enquadernen, y se forme un ýndice para poderlas encontrar quando se buscan, porque si no, son más las que se extravían y andan por afuera que las que quedan, haviendo visto por experiencia que todavía andavan por la Secretaría los despachos y papeles del tiempo del Duque de Uzeda y Monseñor Molines, cuyos negocios pendientes devían ya estar digeridos, y de este descuydo proviene que el archivero se esté olgazán, paseando todo el día, sin atender a la yncumbencia de su oficio, que los papeles en la misma Secretaría se confunden, y que los oficiales de ella, valiéndose de la ocasión del tiempo, dejan de continuar y acelerar sus registros, y las cosas quedan todas retrasadas". 
ampliamente el millar, si bien no se dispone por el momento de un inventario detallado de documentos ${ }^{40}$.

Este corpus documental del Ministerio de Estado cuenta para su acceso con los instrumentos de descripción mecanografiados IDDs (10)003.001 a (10)003.010, a disposición en Sala de Consulta, que ofrecen al investigador una descripción somera de series, asuntos, fechas extremas y países. Ante la todavía escasa profundidad de la descripción disponible para estas series, es de prever que en el futuro puedan salir a la luz un mayor número de referencias documentales de interés para el modernista.

Finalmente, es necesario mencionar los documentos de origen diplomático que heredó la Presidencia del Gobierno al asumir en 1925 los asuntos coloniales y de protectorado en África a través de la Dirección General de Marruecos y Colonias ${ }^{41}$. Bien temprano llegaron al archivo de ese centro directivo todas las series documentales generadas por la antiguas Secciones de Marruecos y Colonias del Ministerio de Estado, y desde la Presidencia del Gobierno fueron transferidas al Archivo General de la Administración en enero de $1981^{42}$. Forman los testimonios más antiguos del llamado "Fondo Histórico de Marruecos" expedientes y correspondencia de la Secretaría de Estado sobre asuntos relativos al Norte de África desde el último tercio del siglo XVIII, sobre todo del Imperio Jerifiano y Berbería, pero también sobre Gibraltar y las islas de Fernando Poo y Annobón y su toma de posesión por España en $1779^{43}$. Destaca especialmente la correspondencia diplomática del Conde de Floridablanca con el Consulado en Tánger y otras autoridades. Como es natural, los temas de navegación, comercio y piratería son predominantes en esta documentación sobre las relaciones internacionales en el Mediterráneo Occidental, muy aprovechable en unión de otros fondos ultramarinos custodiados en el resto de Archivos Estatales.

\section{Los expedientes del Consejo de Guerra (1597-1834)}

Aunque el Archivo General de la Administración fue creado para serlo exclusivamente de la Administración Civil del Estado, y no de la Militar, que siempre ha contado con su propio sistema de archivos, con todo, en los años 1994, 1995 y 1998 el Archivo General del Ministerio de Defensa remitió en sendas transferencias 3.540 cajas,

40 AGA, Asuntos Exteriores, cajas 54/05233-54/05240. El Archivo General de la Administración guarda otra de estas colecciones facticias en la serie de Asuntos Generales de la Subsecretaría de la Presidencia del Gobierno, bajo la denominación de "expedientes abultados". Se trata de una colección de "Reales cédulas, provisiones, autos acordados y otras soberanas disposiciones", también impresas, del período 1730-1884, accesibles a través del inventario IDD (09)002.008; abarcan las signaturas 51/00444-51/00447, correspondiendo las tres primeras al período $1730-1814$.

41 Por Real Decreto de 15 de diciembre de 1925. Su artículo 13 regula la entrega de Archivos.

42 AGA, Registro General de Entrada de Fondos, transferencia registrada con el número 527. Se trata de la gran transferencia de fondos sobre el África española, que propició la creación de la famosa Sección de África del Archivo General de la Administración, con los documentos de la antigua Dirección General de Marruecos y Colonias, la Alta Comisaría de España en Marruecos, las Intervenciones Territoriales del Protectorado en Marruecos y otros organismos.

43 Los documentos más antiguos que referimos se encuentran en las cajas 81/00007, 81/00010, 81/00080, 81/00081, 81/00099, 81/00201, 81/00202, 81/00226, 81/00227, 81/00229, 81/00271, 81/00274, 81/00275, $81 / 00331,81 / 00381,81 / 12879$ y $81 / 12933$. El principal instrumento de descripción disponible es el inventario mecanografiado IDD (15)017.000, si bien pronto se pondrá a disposición del público en PARES. 
contenedoras de más de 196.000 expedientes integrantes de una serie denominada de "Causas, cruces, retiros y casamientos" de personal militar, con fechas extremas situadas entre 1597 y 1965, cuyo último productor había sido el Consejo Supremo de Justicia Militar (1939-1987), pero que sorpresivamente también albergaba documentos del antiguo Consejo de Guerra nacido con los Austrias, y que son suplementarios de los albergados en el Archivo General de Simancas y en el Archivo General Militar de Segovia.

Como es conocido, no existe una fecha exacta de arranque de esta institución, que en sus orígenes se confunde notablemente con el Consejo de Estado, pero en cualquier caso puede reconocerse desde al menos la década de 1580 un Consejo de Guerra plenamente formado dentro del marco del sistema polisinodial y con competencias delimitadas, consistentes en el apoyo consultivo al monarca en materias militares, la gestión administrativa de la Armada y el Ejército, la selección de los cargos militares y la impartición en última instancia de la justicia referente al fuero militar, tarea ésta que con el paso del tiempo se iría convirtiendo en preponderante. Dotado de una sola secretaría o de dos, de Mar y de Tierra, sus integrantes eran expertos militares y diplomáticos, togados y de capa y espada, repartidos en dos salas, muchos de ellos miembros del Consejo de Estado, pues hasta 1714 lo fueron también del de Guerra. La denominación escueta de Consejo de Guerra llega hasta el año 1714, en que pasa a denominarse Consejo Supremo de Guerra, y en 1834 es suprimido junto al resto de Consejos del Antiguo Régimen. Con todo, las altas competencias judiciales en el fuero militar son de alguna manera recogidas por el Tribunal Supremo de Guerra y Marina, creado por Real Decreto de 24 de marzo de ese mismo año; desde 1878 y hasta 1931 continuará como Consejo Supremo de Guerra y Marina, sufriendo diversos cambios de adscripción y denominación que desembocan en la franquista de Consejo Supremo de Justicia Militar, en título último ${ }^{44}$.

En la serie de "Causas, cruces, retiros y casamientos" del Consejo predominan en número los expedientes contemporáneos. Su denominación, una yuxtaposición de asuntos, aglutina en realidad diferentes series generadas por las Salas del Consejo en función del negocio jurídico tratado, de modo que los expedientes vistos por la Sala de Justicia versan sobre causas judiciales incoadas a personas sujetas al fuero militar y el resto, esto es, los vistos por la Sala de Gobierno, son expedientes relativos a la concesión de cruces y recompensas, permisos de matrimonio y clasificación de pensiones de retiro a favor del personal militar o sus familiares. Con todo, tuvieron un tratamiento archivístico unificado, pues en un mismo expediente podían acumularse subexpedientes sobre negocios diversos, desde causas judiciales hasta pensiones de retiro u orfandad. En definitiva, evidencian estos expedientes las competencias del Consejo a partir de 1834 .

44 No es posible en este espacio mencionar toda la legislación sobre funciones, composición y modo de proceder del Consejo de Guerra durante la Edad Moderna, por lo que se remite al lector a la obra de Domínguez Nafría, J. C.: El Real y Supremo Consejo de Guerra (siglos XVI-XVIII), Madrid, Centro de Estudios Políticos y Constitucionales, 2001, si bien no puede dejarse de destacar la Real Cédula de 3 de octubre de 1714 ordenando el cumplimiento del decreto de 23 de abril del mismo año por el que se da nueva planta al Consejo de Guerra, en AHN, Consejos, libro 1474, fols. 363r-365v. Para la Edad Contemporánea, predominante en la cronología de este fondo, es imprescindible el reglamento orgánico del Consejo Supremo de Guerra y Marina publicado por Real Decreto de 17 de diciembre de 1890. 
¿Y qué ocurre con los expedientes de época anterior, de los siglos XVI al XVIII? Aunque todavía no conocemos con detalle todas las tipologías o subseries, dado que el instrumento actualmente disponible para acceder a este conjunto documental es un simple índice onomástico desprovisto de cualquier calificador o dato adicional que pueda dar luz sobre el asunto de cada unidad, las catas hasta ahora efectuadas permiten identificar expedientes relativos al nombramiento de Consejeros de Guerra, memoriales y hojas de servicios de militares, expedientes de concesión de pensiones y cédulas de preeminencias militares y expedientes personales de oficiales y empleados del Consejo. Cuando se complete la descripción precisa de cada unidad documental, que en marcha está, podremos presentar una tipología detallada de las distintas subseries identificadas. En cualquier caso, sí es posible afirmar que todos los expedientes tienen un denominador común: versan exclusivamente sobre personal, bien sean integrantes del propio Consejo, bien militares que se dirigen al mismo para resolver algún negocio o consignar sus servicios.

Los expedientes de nombramiento de Consejeros de Guerra suelen ser muy breves, destinados a testimoniar documentalmente la incorporación del nuevo miembro a la institución colegiada y la notificación de la merced real al interesado, siendo fundamentales el real decreto original y el testimonio de juramento del cargo. En ocasiones superan la formalidad burocrática y nos acercan a las realidades sociales del Antiguo Régimen, como ocurre en el expediente de nombramiento del Conde de Morata ${ }^{45}$, que nos incluye un interesante relato de lo que ocurrió el 8 de enero de 1623 con motivo de su juramento como Consejero de Guerra. Estando reunido el Consejo, el de Morata tuvo que esperar en la puerta, "a la lumbre", junto a los porteros y pajes, a que llegara el Duque del Infantado ${ }^{46}$. En el ínterin iban entrando los consejeros, y entre ellos cambiaban impresiones sobre la indecencia de la compañía y el lugar en que quedaba el conde. No llegando finalmente el del Infantado, y no sufriéndose más la situación, se le hizo entrar para verificar el juramento, ante el Marqués de Villafranca. En cualquier caso, los expedientes de nombramiento son de gran interés para el interesado en los procedimientos y prosopografía de la institución.

Otros expedientes nos hablan de los méritos de guerra y servicios de los militares, generalmente expresados en forma de certificación expedida por los mandos de las unidades u otras autoridades y remitidas al Consejo de Guerra en orden a lograr la concesión de una pensión, remuneración o ayuda de costa. Estos documentos "biográficos" adoptan en ocasiones rasgos dramáticos, como en la carta fechada en Orán el 15 de enero de 1710 dirigida por el artillero José Agustín Pardo de Buenrostro a su esposa Beatriz Quintero, dando cuenta del naufragio de la saetía en la que había zarpado desde Málaga con bastimentos y presidiarios para Melilla, y que dio de través por "tormenta grande", arrojando a sus supervivientes a las costas de Berbería, donde fueron hechos cautivos. La carta forma parte de una información sobre el suceso instruida ante el alcalde mayor de Málaga con objeto de solicitar ayuda para el rescate del militar, perteneciente a la Compañía de Artilleros con sueldo de esa ciudad $^{47}$.

45 Antonio Manrique de Lara y Luna, fallecido en 1624.

46 Juan Hurtado de Mendoza de la Vega y Luna, VI Duque del Infantado, muerto en 1624.

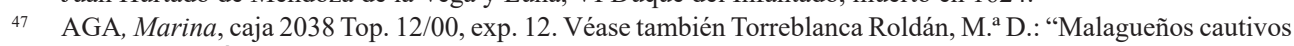
en el norte de África (siglo XVIII)", Aldaba. Revista del Centro Asociado a la UNED de Melilla, 21 (1993), pp. 227-252, donde se cita un fragmento de esta misma información, conservada en este caso en el Archivo de la Catedral de Málaga. 
Por último, los expedientes personales de empleados del propio Consejo de Guerra nos presentan a la mano de obra, más humilde, que permitía el funcionamiento cotidiano de la maquinaria burocrática, desde porteros y mozos de "estrados" hasta relatores. En este artículo no puede dejarse de destacar el expediente de José Rodríguez Argüelles, archivero del Consejo de Guerra entre 1777 y 1820, pues los datos que alberga no son únicamente los biográficos de este funcionario, sino también los que permiten dar luz sobre el Archivo General del Consejo de Guerra a fines del Antiguo Régimen. Las consultas que en él se hallan permiten saber que en noviembre de 1773 Carlos III ordenó al Consejo arbitrar los medios para ordenar el Archivo de la institución comisionando a tres miembros, "quienes, después de haber examinado el estado del antiguo Archivo expusieron que en el quarto de la Casa de los Consejos se hallaban varios legajos de papeles y expedientes sin inventario ni coordinación, unos en estantes y otros en tierra, que unos y otros contenían muchos documentos correspondientes a los antiguos Consejos de Estado ${ }^{48}$ y del de Italia, y que consideraban precisa su traslación a este Consejo", lo que se hizo. Más documentos de este expediente personal permiten reconstruir las metodologías de trabajo, los inventarios e índices elaborados, las dificultades materiales y presupuestarias, las incidencias durante el gobierno josefino y la restauración borbónica hasta el año 1820 , en que falleció el archivero, sin dinero alguno que permitiera costear su entierro. Este funcionario comenzó su carrera de archivero en 1777 como escribiente "entretenido" (esto es, meritorio, sin sueldo), ascendió a oficial del mismo en 1787 y finalmente fue elevado en 1791 a "archivero general", sustituyendo tras su muerte al mismo Tomás de Iriarte, quien reconocía en el mismo expediente que no pudo dedicar mucho tiempo a las tareas archivísticas ${ }^{49}$.

Quien desee adentrarse en los filones informativos de esta serie de personal del Consejo de Guerra tiene a su disposición en la Sala de Consulta un instrumento en forma de base de datos, IDD (02)078.001, que permite la localización de expedientes por criterio onomástico. La información cronológica disponible permite atisbar los siguientes volúmenes de expedientes para el período de existencia del Consejo de Guerra hasta 1834, a saber: 1 para el siglo XVI; 172 para el siglo XVII ${ }^{50} ; 527$ para el siglo XVIII; y 807 para el período 1801-1834. Aunque minoritarios respecto a los expedientes de militares contemporáneos, constituyen un volumen no desdeñable para todos los interesados en la carrera militar en la Edad Moderna y el personal del Consejo, o en la mera recuperación de datos biográficos de antepasados. A fecha de hoy se encuentra iniciado el proceso de descripción y digitalización completas de esta serie con el objetivo de que tanto los registros descriptivos como las imágenes de los expedientes sean accesibles en el Portal de Archivos Españoles (PARES).

48 La estrecha vinculación de los Consejos de Estado y Guerra a nivel funcional y documental podría explicar la presencia en esta serie del expediente de nombramiento del Conde de Floridablanca, a la sazón titular de la Primera Secretaría de Estado y del Despacho como Consejero de Estado el 31 de enero de 1777, en AGA, Marina, caja 116 Top. 83/71, exp. 24.

49 AGA, Marina, caja 2038 Top. 12/00, exp. 1. Lamentablemente, no figura en esta serie el expediente personal del fabulista como archivero del Consejo de Guerra.

50 Los expedientes del siglo XVII han sido estudiados por Elisa Avilés Betegón en "El Consejo de Guerra en el AGA: una aproximación a la serie de "Causas, cruces, retiros y casamientos" del siglo XVII", Cuadernos de Historia Moderna, 33 (2008), pp. 153-173. 


\section{Los fondos de los Corregimientos: Madrid y Alcalá de Henares}

Aun no existiendo en el Decreto 914/69 de creación del Archivo General de la Administración referencia alguna a la incorporación de fondos generados por la Administración de Justicia, lo cierto es que, al igual que ocurre en los Archivos Históricos Provinciales, son multitud los fondos del poder judicial que han ingresado en el centro alcalaíno. Los hay de alcance nacional, como los del Tribunal Supremo, la Audiencia Nacional o el extinguido Juzgado de Delitos Monetarios; de alcance provincial como los de la Audiencia Provincial de Madrid, Tribunal Tutelar de Menores de Madrid o los Juzgados Especiales de Vagos y Maleantes y Peligrosidad y Rehabilitación Social de Madrid; de alcance territorial intraprovincial, como los Juzgados asentados en las cabezas de partido; y de alcance local, como los Juzgados de Primera Instancia y de Instrucción de la capital madrileña y Juzgados Municipales.

Como hemos podido comprobar en otros grupos documentales, también en este caso ingresaron junto a los fondos contemporáneos testimonios de períodos más antiguos. Algunos restos del fondo documental del Corregimiento de Madrid ingresaron en las transferencias de legajos procedentes de los Juzgados de la capital verificadas a lo largo del año $1985^{51}$. Los documentos de esta institución gubernativa y judicial fueron identificados, reinstalados y descritos en 2015, resultando un total de 974 unidades documentales instaladas en 61 cajas (signaturas 81/1896981/19029), con fechas extremas situadas entre 1568 y 1931, si bien predominan los testimonios de los siglos XVIII y XIX. Lamentablemente, más de la mitad de este conjunto documental presenta un estado de conservación regular o malo, debido a la humedad del local de custodia previo a su traslado a Alcalá, por lo que la posibilidad de acceso está lógicamente limitada a este condicionante material. En cuanto a sus tipologías documentales, se trata mayormente de pleitos criminales y civiles y documentos aportados a ellos, informaciones, declaraciones, curadurías, súplicas y peticiones y testamentarías, esto es, asuntos que testimonian la función del Corregimiento de Madrid, sobre todo en su vertiente jurisdiccional, con alcance a la propia Villa y Corte y al territorio de su partido. Actualmente es accesible a través del inventario IDD (07)042.011, que desciende hasta el nivel de unidad documental, estando prevista la disponibilidad de los registros descriptivos correspondientes en el Portal de Archivos Españoles (PARES). Complementa sin duda a los 632 legajos del Corregimiento custodiados en el Archivo General de la Villa de Madrid $^{52}$ y, dada su especial conexión jerárquica con el Consejo de Castilla, al fondo documental de dicha institución albergado en el Archivo Histórico Nacional.

Más relevante en su volumen y mejor conservado es el fondo del Corregimiento de Alcalá de Henares (1524-1870), ingresado el 30 de junio de 1980 junto a las series contemporáneas del Juzgado de Primera Instancia e Instrucción de la ciudad ${ }^{53}$. De los

51 AGA, Registro General de Entrada de Fondos, transferencias registradas con los números 800 y 808 , ingresadas en junio y octubre de 1985 .

52 Está constituido este fondo por nombramientos, visitas y residencias (1219-1888) y documentos relativos a pueblos de la jurisdicción de Madrid (elección de justicias, apeos y reconocimientos de términos, memoriales, peticiones e informes, siglos XV-XIX): Cayetano Martín, M. ${ }^{a}$ del C.: Archivo de Villa 2001, Madrid, Ayuntamiento de Madrid, 2001, p. 64.

53 AGA, Registro General de Entrada de Fondos, transferencia registrada con el número 498, y asignada al Grupo de Fondos de Justicia. Al parecer, los fondos que integraban esta transferencia fueron organizados originariamente en el propio Juzgado de Alcalá, y remitidos al Archivo de la Audiencia Provincial de Madrid, 
650 legajos originales, los documentos del Juzgado alcalaíno de los siglos XIX y XX se agrupaban en series de diligencias, sumarios penales, pleitos civiles, expedientes sociales, subastas de bienes nacionales y expedientes del ramo gubernativo, acompañados de los correspondientes libros registro; pero junto a ellos se descubrió un importante conjunto documental procedente del período anterior a la creación del Juzgado de Primera Instancia e Instrucción, que fue adscrito al Corregimiento de Alcalá de Henares, y que fue heredado al asumir el nuevo Juzgado las funciones jurisdiccionales en el ámbito local y en el partido judicial a partir del segundo tercio del XIX. Las primeras actuaciones fueron realizadas por la primera y segunda Escuela-Taller de Archivos entre 1991 y 1993, y dieron a lugar a la identificación, organización y primera instalación del fondo, surgiendo dos inventarios someros, el IDD (07)041.001, propio del Juzgado de Primera Instancia e Instrucción, y el IDD (07)042.002, para el Corregimiento y otros organismos relacionados con el Juzgado de Alcalá, como el Juzgado Mixto de la Propiedad Rústica (1929-1937), el Juzgado Municipal de Canillas (1895-1906), el Juzgado Municipal de Torrejón de Ardoz (1900-1902), el Juzgado Municipal de Vallecas (1922-1923) y el Tribunal de Subsistencias (1937-1939), junto a entidades no jurisdiccionales como la Comisión de Pósitos (1771-1831), el Ayuntamiento de Camporreal (1907) y la Casa de Comercio de Juan de Lezameta (1835-1849). El fondo fue reinstalado, convirtiéndose los 650 legajos en 1.542 unidades normalizadas de instalación. A lo largo de las dos primeras décadas del siglo XXI se ha trabajado en colaboración con el Taller de Empleo de Archivos de la Universidad de Alcalá de Henares para la descripción integral del fondo del Corregimiento hasta el nivel de unidad documental, de cara a su próxima puesta a disposición al público en el Portal de Archivos Españoles (PARES), donde también podrá accederse a buena parte de las imágenes digitales.

El fondo del Corregimiento de Alcalá (1524-1870) está formado en la actualidad por un total de 172 cajas normalizadas, goza en general de buen estado de conservación (con las salvedades habituales) y se estructura en cuatro divisiones de fondo: Gobierno, Justicia, Jurisdicción eclesiástica y Fe pública notarial. Las tres primeras testimonian la función del Corregidor como máxima autoridad gubernativa y judicial en la demarcación del partido. Las funciones gubernativas se plasman en expedientes sancionadores en el ámbito del concejo (infracciones por asuntos de pastos, precios, compraventas, etc.) y, en el ámbito del partido judicial, en forma de expedientes sobre pósitos de abastecimiento, entre otros asuntos. Las funciones judiciales tienen su expresión material, en el orden penal, en las tradicionales causas criminales; en el ámbito civil, en cuentas de curaduría, concursos de acreedores, testamentarías, pleitos de cuentas, pleitos ejecutivos, pleitos ordinarios e informaciones; y en el ramo judicial gubernativo, en expedientes de variada índole, muchas veces diligencias previas a la apertura de un procedimiento penal o civil. La división que concierne a la jurisdicción eclesiástica es testimonio de la presencia de una potente autoridad religiosa en Alcalá de Henares, como no podía ser de otro modo al estar la ciudad bajo el señorío del Arzobispo de Toledo y ser la sede de su vicaría general, además de acoger la Universidad y sus colegios y conventos. Todo ello se evidencia en forma de pleitos, autos y otros documentos judiciales, que se complementan con los fondos del Archivo Histórico Nacional y el Archivo

desde donde fueron remitidos finalmente al Archivo General de la Administración en la fecha indicada, pero ya en estado de desorden. 
Municipal de Alcalá. Es excusado enumerar todas las posibilidades que ofrecen a la investigación estas series gubernativas y judiciales, con el aliciente de tener su data en un espacio social y cultural donde confluyen cuatro grandes poderes: el real, el eclesiástico, el universitario y el municipal.

Finalmente, la división correspondiente a la fe pública notarial engloba un pequeño conjunto de protocolos notariales y escrituras públicas de la Edad Moderna que ya fue detectado en la década de 1990 y que han sido objeto de descripción precisa en los últimos años. La pregunta es, ¿por qué aparecieron estos documentos notariales mezclados con los papeles judiciales del Corregimiento? Desde luego parece haber sido el resultado de la concentración física de los protocolos históricos en el edificio del Juzgado y Prisión de Partido de Alcalá de Henares (hoy Museo Arqueológico de la Comunidad de Madrid). Los protocolos notariales del partido alcalaíno anteriores a 1832 fueron trasladados provisionalmente al vecino Archivo General Central entre junio y julio de 1932 a la espera de su traslado definitivo al Archivo Histórico de Protocolos de Madrid, cosa que no pudo verificarse al ser pasto de las llamas el primero el 11 de agosto de 1939. La pérdida fue inconmensurable, pues esos 2.300 legajos, calificados de "relicario nacional" y fuente para "una verdadera renovación de la historia social de España" ${ }^{54}$, testimoniaban las transacciones y disposiciones de los habitantes de Alcalá de Henares durante la Edad de Oro de la localidad, en que estuvieron activas las facultades y colegios de su Universidad. Sus famosas imprentas, que dieron a la luz la Biblia Políglota Complutense o La Galatea de Cervantes, carecen hoy de estas importantes fuentes. Los escasos protocolos alcalaínos conservados en el Archivo General de la Administración permiten recuperar una pequeña muestra de ese universo editorial, como el poder otorgado el 11 de noviembre de 1556 por Francisca de Angulo a favor de su hermano Andrés para hacerse cargo de la imprenta de su marido, el difunto Juan de Brocar, hijo del impresor de la Biblia cisneriana, Arnao Guillén de Brocar ${ }^{55}$.

Así pues, los documentos notariales que han sobrevivido en el fondo del Corregimiento, probablemente albergados en las oficinas del Juzgado y salvados por no haberse incluido en la fatídica remesa de 1932, tienen el triste valor añadido de la rareza y excepcionalidad de su conservación hasta nuestros días. Se trata de registros de escrituras públicas de los escribanos Juan Ferrández (1558-1565), Pedro de Madrid (1575-1580), Antonio de Madrid (1575), Eugenio de Villalba (1594), Pedro de Cuéllar (1597), Gabriel López de la Flor (1597-1609), Salvador Fernández (1597-1609), Juan de Quintarnaya (1601), Jerónimo Ceballos (1617-1618), Juan de Medina (1626), Manuel de Hita (1658), Juan Antonio de la Torre (1675), Roque Rodríguez Morcillo (1706-1735), Eugenio Martínez de Ayuso (1712-1721), Jerónimo de la Oliva (1752), Tomás Dorado, Nicolás Azaña y Francisco de Huerta

54 AGA, Educación, caja 31/05143. La consideración de "relicario nacional" procede del Ministerio de Justicia; la reflexión sobre la "historia social" es de Miguel Gómez del Campillo, inspector general de Archivos. El traslado se efectuó teóricamente en aplicación del Decreto de 12 de noviembre de 1931 del Ministerio de Justicia, que incorporaba los protocolos de más de cien años de antigüedad al servicio del Cuerpo Facultativo de Archiveros; pero, en el orden práctico, unas obras de acondicionamiento de la Prisión de Partido fueron determinantes para la decisión administrativa de transferir provisionalmente los protocolos al Archivo General Central, distante menos de 100 metros: Gozalbo Gimeno, op. cit. (nota 2), pp. 216-218.

55 AGA, Justicia, caja 44/13380, registro de escrituras públicas del escribano Juan Ferrández de 1556-1557, asiento 1 . 
(1776-1804), José Castellano (1823) y Urbano de Soria (1832-1833) $)^{56}$, a los que se deben añadir 164 escrituras sueltas otorgadas entre 1542 y 1870. Los protocolos notariales del distrito alcalaíno de más de 100 años de antigüedad y posteriores a 1832 se encuentran hoy depositados en el Archivo Histórico de Protocolos de Madrid y en el Archivo Municipal de Alcalá de Henares, donde también existen unos pocos registros de Edad Moderna.

\section{Última consideración}

No podemos poner punto final a este viaje por los documentos más antiguos del Archivo General de la Administración sin hacer mención a un último conjunto documental, éste procedente del Archivo Central del Ministerio de Educación. Se trata de la serie de Asuntos Generales de Establecimientos Culturales y de Enseñanza. Está constituida por expedientes "generales" (con este nombre se suele hacer referencia a la reunión, año a año, de documentos sobre un mismo asunto) que aglutinan los antecedentes documentales de creación y desenvolvimiento de múltiples instituciones culturales y docentes, sean escuelas de primera enseñanza, institutos, universidades, archivos, bibliotecas, museos, academias y sociedades científicas. Algunos de estos expedientes se remontan al siglo XVIII, como es el caso de la Escuela de Bellas Artes de Segovia, la Escuela de Veterinaria de Madrid, la Escuela de Matemáticas de Murcia o la Real Academia Española ${ }^{57}$.

Finalmente, debemos considerar las posibilidades que ofrecen los documentos contemporáneos para la investigación de aspectos de la Edad Moderna. A la mente acuden los datos que pueden aportar los proyectos liberales de carreteras para la indagación sobre el sistema viario del Antiguo Régimen, sobre el que se superpone frecuentemente el nuevo trazado, o los proyectos de restauración de monumentos para la compilación de datos sobre la arquitectura de los siglos XV al XVIII, especialmente en los casos de inmuebles ya desaparecidos. Así, terminando donde se empezó, cabe decir que habría sido muy difícil reconstruir la traza renacentista original del Palacio Arzobispal de Alcalá de Henares, sede del Archivo General Central entre 1859 y 1939 , sin recurrir a los proyectos y expedientes de restauración y conservación generados en los siglos XIX y XX por los Ministerios de Fomento e Instrucción Pública y Bellas Artes que se custodian en sus correspondientes fondos ${ }^{58}$.

56 Signaturas 44/13879-44/13886, 44/13889, 44/13895, 44/13899, 44/13915, 44/13918, 44/13920, 44/13921, 44/13923, 44/13924, 44/13926-44/13928, 44/13930, 44/13931, 44/13938, 44/13940, 44/13956, 44/13973, 44/13979, 44/13986, 44/13988, 44/13993, 44/13995, 44/14000, 44/14005, 44/14006, 44/14008, 44/14010, 44/14017, 44/14018, 44/14020, 44/14025, 44/15423 y 44/15424.

57 Los expedientes de las instituciones docentes son accesibles a través del instrumento en base de datos IDD (05)016,000; los de instituciones culturales a través del inventario IDD (05)001.004 (inventario mecanografiado) e IDD (05)003.000 (base de datos). En el caso de la RAE, los antecedentes se remontan hasta 1725.

58 Son numerosos los instrumentos que dan acceso a las series de restauración y conservación de edificios de interés histórico-artístico, ingresadas en múltiples transferencias, pero desde luego es necesario citar el inventario IDD (05)014.002, en base de datos, que da acceso a los Expedientes de Obras de Construcciones Civiles, generados por los Ministerios de Gobernación y Fomento decimonónicos. Esta serie integra tanto proyectos de restauración como expedientes urbanísticos de ensanches de poblaciones, y ello explica la existencia de más de 130 títulos de propiedad y cargas de las casas expropiadas para el "embellecimiento y ensanche" de la Puerta del Sol de Madrid a mediados del siglo XIX. Las escrituras están datadas entre 1481 y 1858 , y se conservan en 64 cajas: AGA, Educación, cajas 31/08300-31/08363. Algunos edificios oficiales cuentan también con sus 
Valga este informe para la conmemoración en este año 2019 del medio siglo de existencia del Archivo General de la Administración y el reconocimiento a las personas que han integrado su plantilla desde su creación.

\section{Bibliografía}

Avilés Betegón, E.: "El Consejo de Guerra en el AGA: una aproximación a la serie de 'Causas, cruces, retiros y casamientos' del siglo XVII', Cuadernos de Historia Moderna, 33 (2008), pp. 153-173.

Badorrey Martín, B.: Los origenes del Ministerio de Asuntos Exteriores, Madrid, Ministerio de Asuntos Exteriores, 1999.

Bermejo Cabrero, J. L.: Estudios sobre la Administración Central española (siglos XVII y XVIII), Madrid, Centro de Estudios Constitucionales, 1982.

Cayetano Martín, M. C.: Archivo de Villa 2001, Madrid, Ayuntamiento de Madrid, 2001.

Domínguez Nafría, J. C.: El Real y Supremo Consejo de Guerra (siglos XVI-XVIII), Madrid, Centro de Estudios Políticos y Constitucionales, 2001.

Gaite Pastor, J.: "Los Archivos del Ministerio de Hacienda", Studia Historica. Historia Contemporánea, 6-7 (1988-1989), pp. 197-224.

García García, C. y Pro Ruiz, J.: "Arreglar la deuda para consolidar el estado: de Bravo Murillo a García Barzanallana (1851-1867)", en Álvarez Nogal, C. y Comín, F. (eds.): Historia de la deuda pública en España (siglos XVI-XXI), Madrid, Instituto de Estudios Fiscales, 2015, pp. 187-220.

Gozalbo Gimeno, D.: "El Archivo General Central (1858-1939). Aproximación a los fondos documentales desaparecidos", en Chamorro Merino, G. (ed.): El Palacio Arzobispal de Alcalá de Henares. Historia y Arquitectura, Alcalá de Henares, ARPA-Institución de Estudios Complutenses, pp. 199-222.

Maza, E.: Pobreza y beneficencia en la España contemporánea (1808-1936), Barcelona, Ariel, 1999.

Senent Díez, M. P.: "Los privilegios rodados del Archivo General de la Administración Central de Alcalá de Henares", Espacio, Tiempo y Forma, Serie III, Historia Medieval, t. V (1992), pp. 317-336.

Simal López, M.: "El Palacio de España en Roma a través de los dibujos de Ferdinando Puga y José de Hermosilla", Archivo Español de Arte, 321 (2008), pp. 31-48.

Torreblanca Roldán, M. D.: "Malagueños cautivos en el norte de África (siglo XVIII)", Aldaba. Revista del Centro Asociado a la UNED de Melilla, 21 (1993), pp. 227-252.

Val Latierro, F.: "Dirección General de la Deuda y Clases Pasivas", en Guia de los Archivos de Madrid, Madrid, Dirección General de Archivos y Bibliotecas, 1952, pp. 227-253.

Villar Lijarcio, J. J.: "La provincia de Jaén en el Archivo de la Beneficencia Particular", Códice. Revista de Investigación Histórica y Archivística, 26 (2012), pp. 31-40.

títulos antiguos de propiedad, como el Palacio de Viana, desde 1939 residencia oficial y de representación de los Ministros de Asuntos Exteriores, del que se custodian antecedentes desde 1566 en el fondo del Ministerio de Asuntos Exteriores, cajas 82/09151 y 82/09152 (Sección de Compras). 